\title{
偏側性水腎症の腎孟尿成分排泄率を用いた 腎機能回復能予測法の臨床的検討
}

$\begin{array}{ccccc} & \text { 福 } & \text { 崎 } & & \text { 篤 } \\ & \text { 鈴 } & \text { 木 } & \text { 省 } & \text { 司 } \\ \text { 東北大学医学部泌尿器科学教室 } & \text { 金 } & \text { 藤 } & \text { 博 } & \text { 行 } \\ & \text { 岡 } & \text { 田 } & \text { 康 } & \text { 弘 } \\ & \text { 折 } & \text { 笠 } & \text { 精 } & \text { 一 }\end{array}$

\section{PREDICTION OF FUNCTIONAL RECOVERY IN UNILATERAL HYDRONEPHROSIS CLINICAL IMPLICATION OF PELVIC URINE ANALYSIS}

\author{
Atsushi Fukuzaki, Shoji Suzuki, Hiroyuki Kanetoh, Yasuhiro Okada \\ and Seiichi Orikasa \\ Department of Urology, Tohoku University School of Medicine \\ (Director: Prof. S. Orikasa)
}

Fractional excretion rate of pelvic urine component in 35 cases of unilaterally hydronephrotic kidney was analysed to assess functional recoverability of obstructed kidney. Compariong these results with renographic findings, pelvic emptying time and the renal concentration of contrast medium were well correlated with low fractional excretion rate of sodium. However, the degree of dilatation of calices was not correlated with the fractional excretion rate of each urinary component.

On nine cases, arteriography was performed preoperatively. The ratio between the diameter of abdominal aorta and renal artery of obstructed kidney were compared with the fractional excretion rate of each urinary component. Higher aorto-renal arterial diameter ratio, more than $20 \%$, were corresponded to lower fractional excretion rate of sodium. less than $3 \%$, in obstructed kidney. Good operative results were obtained in only such cases.

Late operative results were assessed radiologically in 24 cases. Improvement was obtained in cases with lower fractional excretion rate of sodium preoperatively, i.e. less than $3 \%$. Excellent results were oblained only in cases with preoperative fractional sodium excretion rate less than $2 \%$ and of the age at operation before 15 years old.

These results indicate that, pelvic urine analysis is useful to assess functional status and recoverability of obstructed kidney. We believe that functional recovery will be expected if fractional sodium excretion rate of hydronephrotic kidney is less than $3 \%$.

要旨：35例の偏側性水腎症に対して腎機能回復能評価の目的で腎孟尿中成分の尿中排泄率の分析を拈こ なった。そ結果をIVP 所見と比較すると, 造影に要する時間及び造影度は尿中ナトリウム排泄率が低 値のもので良好であった。しかしながら腎杯の拡張の程度は，尿中各成分排泄率と相関しなかった。

9 例で動脈造影を施行し, 患側腎動脈の対腹部大動脈比と尿中各成分排泄率とを比較した。 その結果, 腎動脈の対腹部大動脈比が $20 \%$ 以上の例では尿中ナトリウム排泄率は $3 \%$ 以下と低值で, 術後良好な結 果が得られた。

24 例について術後レ線上の改善度を検討した. その結果, 術後尿中ナトリウム排泄率が $3 \%$ 以下の例 では改善が得られたが，著明な改善は術前尿中ナトリウム排泄率が $2 \%$ 以下で，手術時の年齢が 15 歳以 下のものに限られた。

これらの結果から, 腎孟尿の分析は尿路閉塞腎の腎機能評価及び回復能の予測に有用であり, 尿中ナ トリウム排泄率が $3 \%$ 以下なら腎機能の回復が見込をれると考兄られた。 


\section{緒 言}

従来より偏側性水腎症の回復能予測の目的で, 様々 な方法が試みられているが，今だに結論をみていない のが現状である，我々は動物実験において，尿路閉塞 中の水腎尿を用いて算出した尿中成分排泄率のうち殊 に, FENa や水腎機能をよく反映し，尿路閉塞解除後 の腎機能回復能の予測に極めて有用であることをすで に報告している1). 今回は臨床例を用いて本法の有用 性について検討を抗こなったので報告する。

\section{方 法}

対象は35例の偏側性水腎症（先天性28例, 後天性 7 例）で，男24例，女11例，年齢は 4 力月から67歳，平 均20.8歳で，ちち20例は15歳以下の小児例である。患 側は左側 26 例, 右側 9 例, 閉塞の部位は腎孟尿管移行 部25例, 尿管膀脱移行部 8 例, 中部尿管 2 例であった. これらに対して経皮的腎孟穿刺により腎昷尿を採取 し，クレアチニンを指標に，下記の計算式を用いて FENa, FEK, 及び V/GFR (Pcr/Ucr) を算出した.

$$
\begin{aligned}
\text { FEx }(\%)= & \frac{\text { Excreten } \mathrm{x}}{\text { Filtered } \mathrm{x}} \times 100 \\
& =\frac{\mathrm{Ux} \times \mathrm{V}}{\mathrm{Px} \times \mathrm{GER}} \times 100 \\
& =\frac{\mathrm{Ux} \times \mathrm{V} \times 100}{\mathrm{Px} \times \mathrm{Ucr} / \mathrm{Pcr} \times \mathrm{V}} \\
& =\frac{\mathrm{Ux}}{\mathrm{Px}} \times \frac{\mathrm{Pcr}}{\mathrm{Ucr}} \times 100
\end{aligned}
$$

$\mathrm{Px}: \mathrm{x}$ の血中濃度, $\mathrm{Ux}: \mathrm{x}$ の尿中濃度, $\mathrm{Pcr}$ : 血 中クレアチニン濃度, Ucr : 尿中クレアチニン濃度 次に各例の静脈性腎孟造影の所見を, 腎杯の形態, 造影に要する時間，造影の濃度から以下のように分類 し，それぞれについて各成分尿中排泄率との比較をお

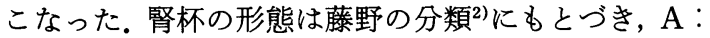
腎杯辺縁部が純円化しているもの，B：腎杯の純円化 は著しいが, 腎杯頝部の明らかなもの, C：腎杯は頝部 を含めて拡張著しいが，乳頭部が区別されるものの， $\mathrm{D}$ ：さらに拡張著しく，乳頭部が区別されないもの,

$\mathrm{E}$ ：腎䡩を含めて囊状となり，腎杯の区別が困難なも の,と $\mathrm{A}$ から $\mathrm{E}$ の 5 段階に分類した。造影に要する時 間は，尿管が描出されるまでの時間，あるいは腎孟が 造影剤で完全に充満され尿管へ排泄されていると考え られるまでの時間を15分以内，15分から60分，60分以 上の 3 段階に分けた。造影の濃度は，尿管が描出され た時点で, 正常側と同程度の濃度で腎昷，腎杯の形態 が充分に観察されらる得るもの，造影は確認し得るが 腎典, 腎杯の詳細な観察には不十分なもの, 施行され
た造影の時間内では肉眼的に造影が確認されないもの の三段階に分類した。いずれも原則として $76 \%$ 水溶性 造影剤 $40 \mathrm{ml}$ (小児では $1 \mathrm{ml} / \mathrm{kg}$ )を約 2 分間かけて静注 したもので比較し,造影されなかった場合の腎杯像は， DIP あるいは経皮的腎孟造影によった，次に血管造影

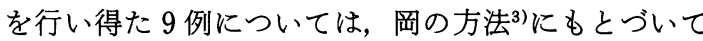
患側腎動脈の対腹部大動脈比を求め, 患側腎孟尿より 算出した尿中各成分排泄率との比較を扣こなった。閉 塞解除後 6 カ月以上の経過観察が可能であった 24 例に ついては，閉塞解除前の患側尿中各成分排泄率と，閉 塞解除後の腎盂造影像上の改善の有無との関係につい て検討を加学た。

\section{結 果}

1. 静脈性腎孟造影像と尿中各成分排泄率との比較

1）腎杯の形態と尿中各成分排泄率との関係

腎孟穿刺を扢こなった一側性水腎症の 35 例を，藤野 の分類 ${ }^{2}$ ともとうき腎杯の形態から 5 段階に分類し た．Aに属する軽度の水腎症は 1 例もなく，Bを 2 例， $\mathrm{C}$ が15例， Dが 7 例， $\mathrm{E}$ が11例であった，各例の腎孟 穿刺尿より算出した各成分尿中排泄率と腎杯の形態と の関係をみると（Fig. 1a, 1b,1c）。腎杯の変化は軽度 でも各成分尿中排泄率は高値のものがあり, 逆に腎杯 の変化は著しいものでも，各成分尿中排泄率は低值の ものも認められ, 腎杯の形態的変化と各成分尿中排泄

Fig. 1a Relationship between V/GFR of pelvic urine in hydronephrosis and the degree of dilatation of calices.

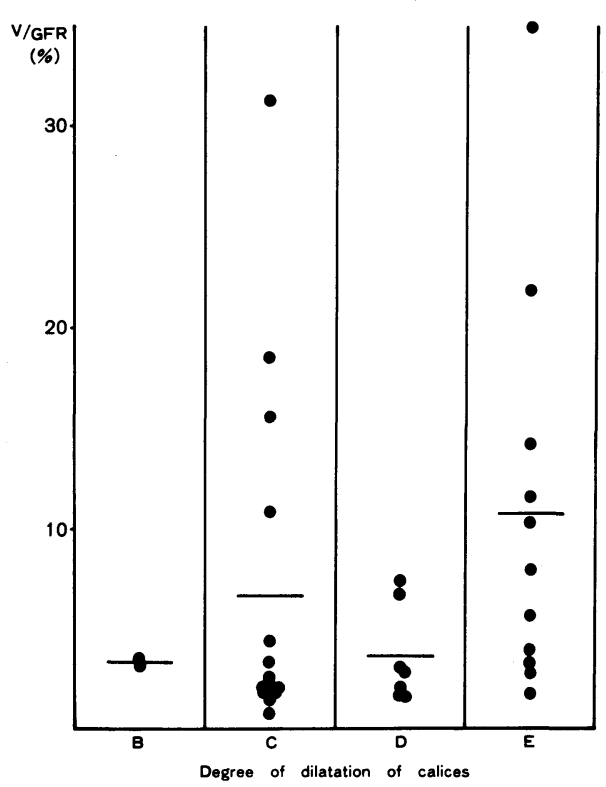


Fig. 1b Relationship between FENa of pelvic umrine in hydronephrosis and the degree of dilatation of calices.

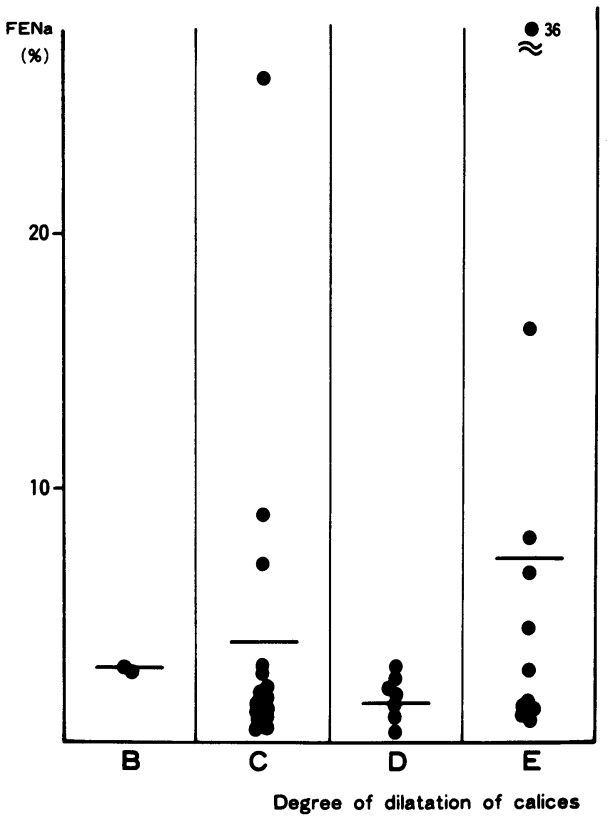

Fig. 1c Relationship between FEK of pelvic urine in hydronephrosis and the degree of dilatation of calices.
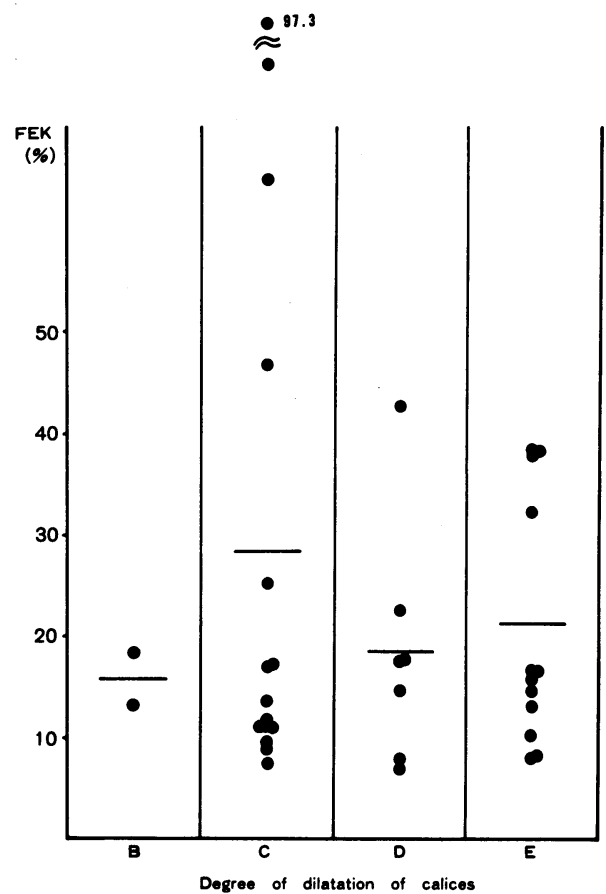

率とは必ずしも相関しないことが明らかである。

2）造影に要する時間と尿中各成分排泄率との関係 造影剂静注後 15 分以内に尿管が描出されたのは 5 例，15分以上 60 分以内に描出されたのは17例で，いず れも腎盂尿の尿中各成分排泄率は低值であったが，殊 に尿中ナトリウム排泄率（FENa）は全例 $3 \%$ 以下で あった（Fig. 2a, 2b, 2c). 造影に60分以上を要したも のは13例で，ほとんどの例で各成分尿中排泄率は高值 であった。

3）造影の濃度と各成分尿中排泄率の関係

対側正常腎と同程度の造影濃度が得られたのは14例 で，いずれも各成分尿中排泄率は低值の傾向であった が，殊に尿中カトリウム排泄率 (FENa) は全例 $3 \%$ 以 下であった。

また造影は不良であるが，造影を確認し得たものは11 例で, この群の FENa むやはり低值であった。これに 対して不映腎と考えられる10例は，2 例を除いていず れも FENa $3 \%$ 以上と高値であった（Fig. 3a，3b, 3 c).

2. 患側腎動脈の対腹部大動脈比と尿中各成分排泄 率との比較

Fig. 2a Relationship between V/GFR of pelvic urine in hydronephrosis and time at ureter visualized.

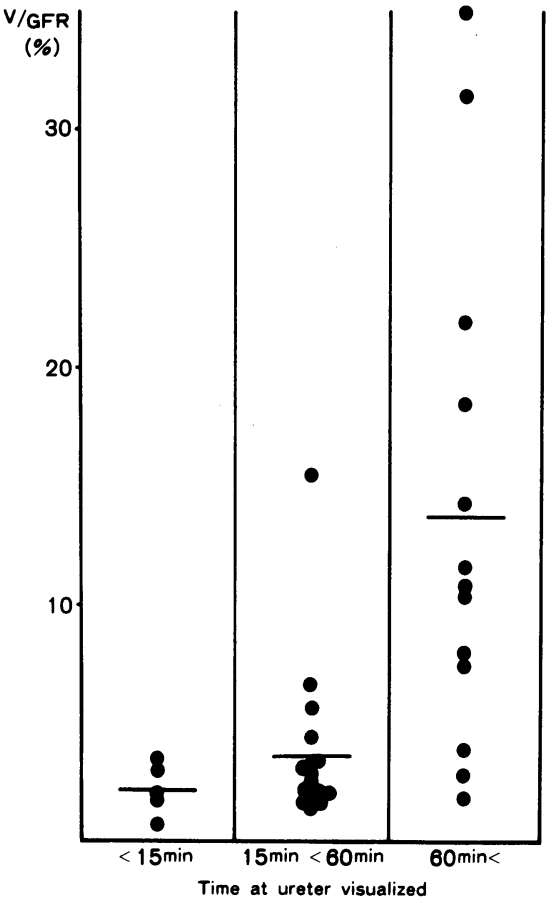


Fig. 2b Relationship between FENa of pelvic urine in hydronephrosis and time at ureter visualized.

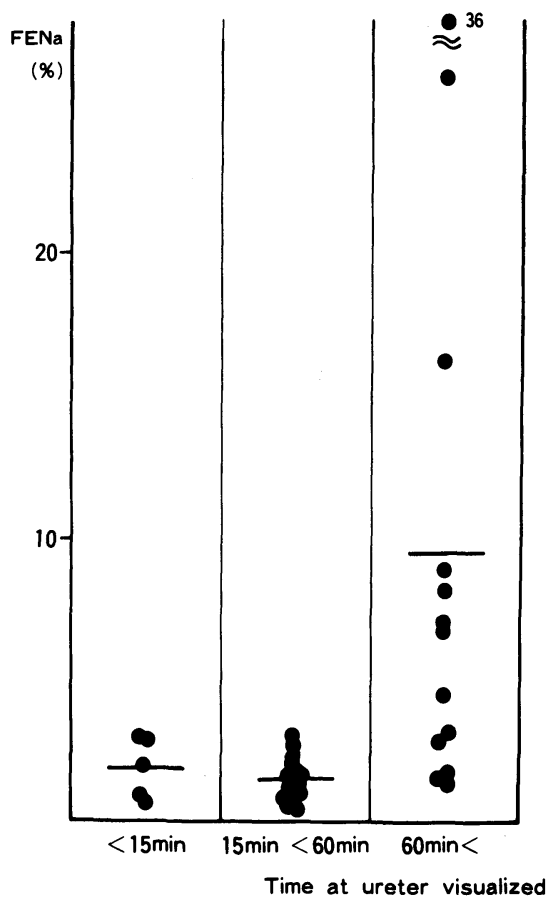

動脈造影を施行した 9 例について, 岡の方法3)にも とづいて患側腎動脈及び腹部大動脈の直径を測定し, 腎動脈の対腹部大動脈比を算出した。これらの 9 例は いずれも手術を行っているが，腎摘を施行した 1 例を 含めて腎動脈の対腹部大動脈比が $20 \%$ 以下の 4 例は, いずれも術前患側腎盂尿の FENaは $4 \%$ 以上と高値 であった。このうち 3 例は閉塞解除手術を施行したが， 術後もIVP 上の改善は得られなかった。一方, 腎動脈 の対腹部大動脈比が $20 \%$ 以上の 5 例はいずれも腎孟尿 の FENa は $3 \%$ 以下で, 術後 IVP 上の改善をみてい る (Fig. 4a, 4b, 4c).

3. 閉塞解除前の患側尿中各成分排泄率と術後結果 との比較

術前腎孟穿刺を抢こない, 閉塞解除後 6 カ月以上経 過を観察し得た 24 例（先天性 20 例, 後天性 4 例）につ いて, 手術後の静脈性腎孟造影像上の改善の有無を検 討した. 静脈性腎孟造影像の前述の如く, 腎杯の形態, 造影時間, 造影濃度の三項目についてそれぞれ分類し， Johnston らの方法4)の如くそれぞれの項目ごとに術前 と比較して, 改善, 不変, 増悪と三段階に評価したう えで，さらにこのらち二項目以上に改善が認められた
Fig. 2c Relationship between FEK of pelvic urine in hydronephrosis and time at ureter visualized.

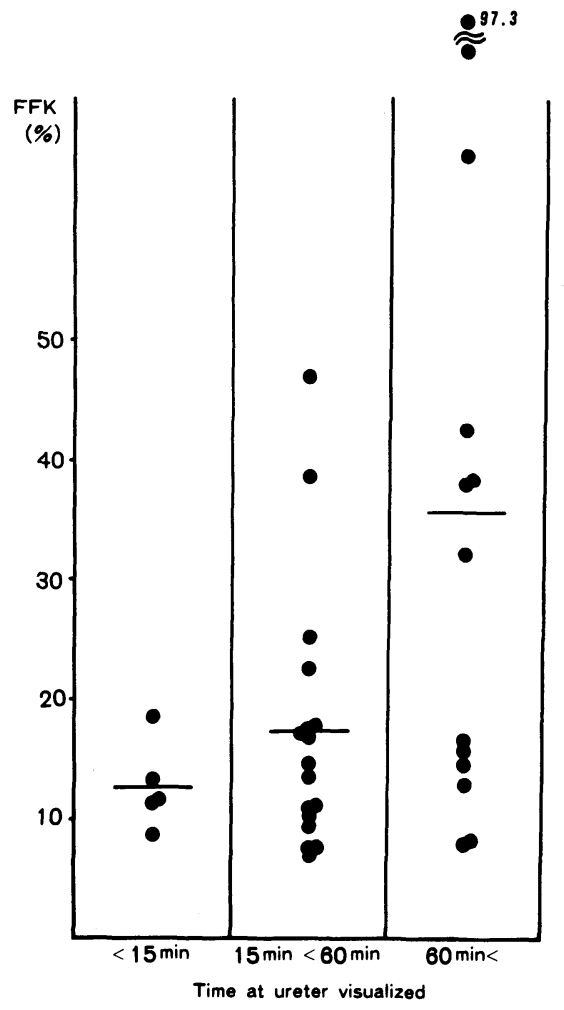

ものを“著明に改善”，一項目のみに改善が認められた すのを“改善”，いずれの項目にも改善がみられなかっ たもの（不変及び増悪）を“改善せず”として，総合判 断を扣こなった。 その結果，改善の認められた例では， いずれも各成分尿中排泄率は低值であったが，殊に FENa にその傾向が著しかった。をた著明な改善例は いずれす FENa $3 \%$ 以下であった (Fig. 5a, 5b, 5c).

この結果を手術時の年齢とともに検討すると，著明 な改善の得られた例は，15歳以下で術前の尿中ナトリ ウム排泄率(FENa)が $2 \%$ 以下のものに限られた。 た手術時の年龄にかかわらず，術前 FENa が $3 \%$ 以下 のものでは，いずれも腎孟造影像上の改善が認められ た。これに対して，術前の水腎尿中ナトリウム排泄率 （FENa）が $4 \%$ 以上であった 4 例は，術後も腎孟造影 像上の改善は得られなかった (Fig. 6).

\section{考按}

尿路の閉塞は，腎に水腎化といら形態的変化をもた らし，最終的に腎は著しい機能障害に陥るが，閉塞を 解除することにより腎機能の回復する可能性が見込ま 
Fig. 3a Relationship between V/GFR of pelvic urine in hydronephrosis and/concentration of contrast medium.

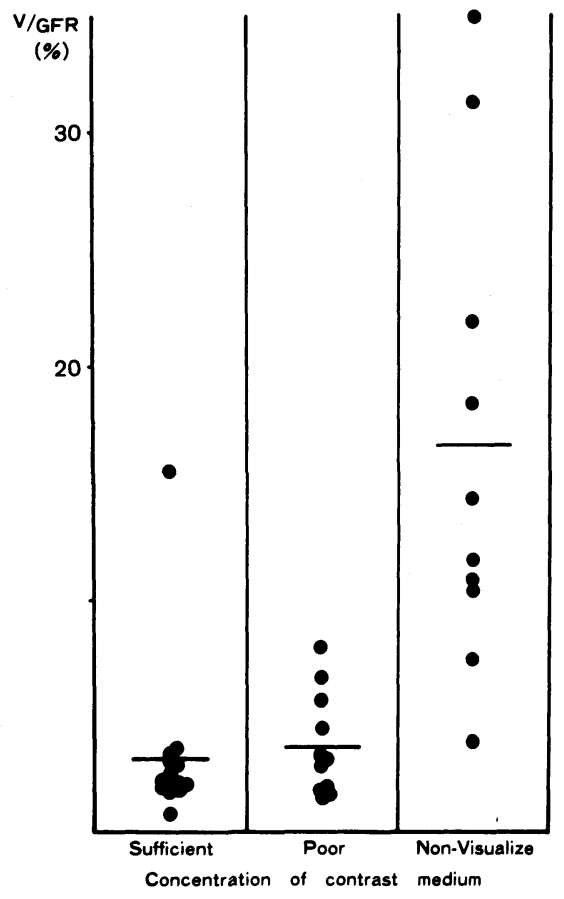

Fig. 3b Relationship between FENa of pelvic urine in hydronephrosis and concentration of contrast medium.

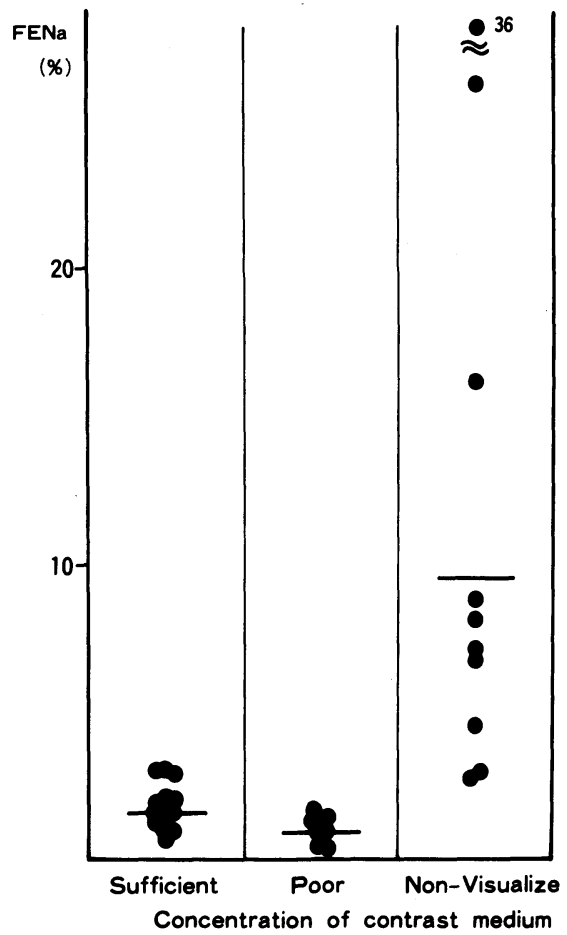

Fig. 3c Relationship between FEK of pelvic urine in hydronephrosis and concentration of contrast medium.

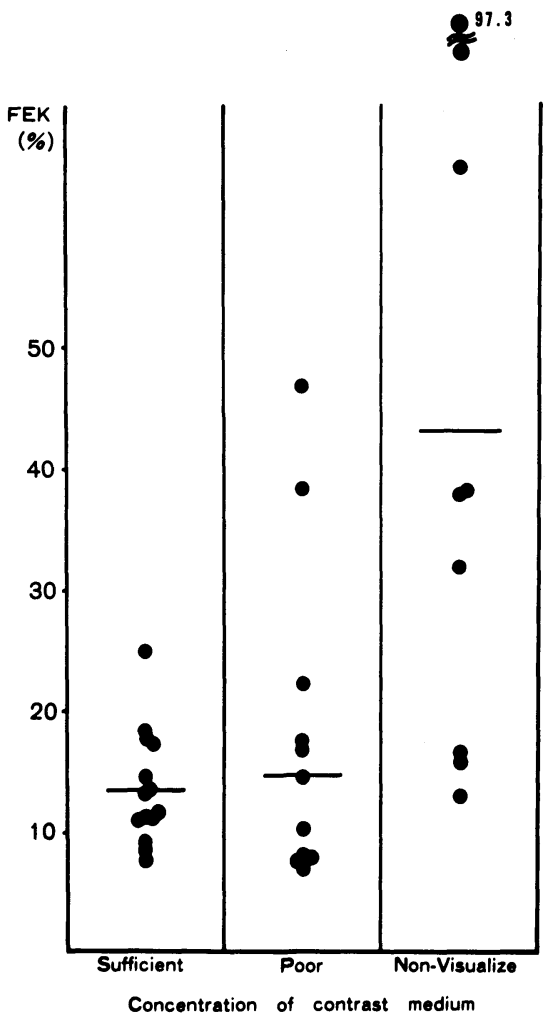

Fig. 4a Relationship between V/GFR of hydronephrotic kideney, aorto-renal artery diameter ratio and results of operation.

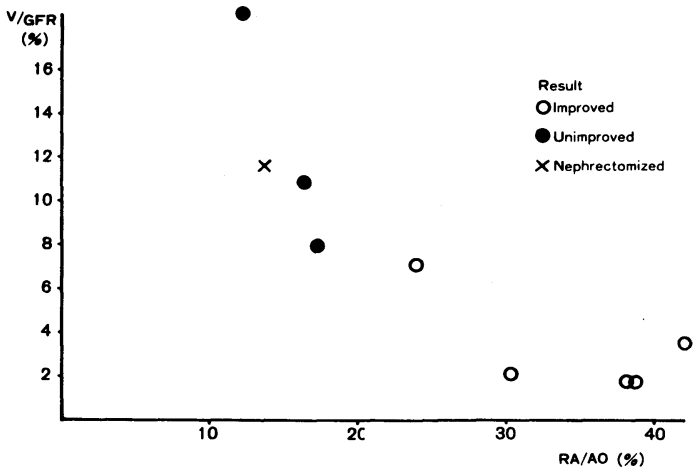


Fig. 4b Relationship between FENa of hydronephrotic kidney, aorto-renal artery diameter ratio and results of operation.

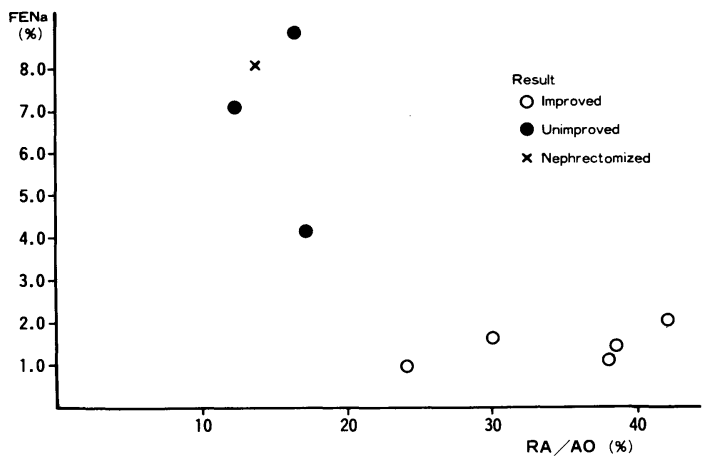

Fig. 4c Relationship between FEK of hydronephrotic kidney, aorto-renal artery diameter ratio and results of operation.

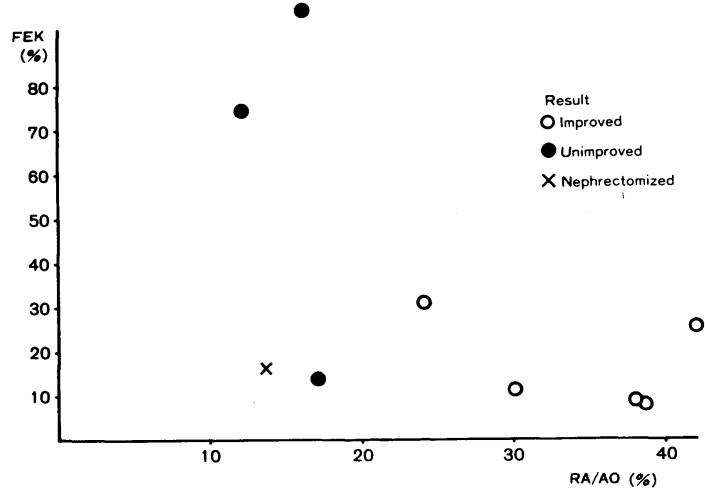

れるだけに，障害腎の残存機能と回復能を把握する必 要がある。殊に一側性尿管閉塞による偏側性水腎症で は，対側腎の代償性肥大により総腎機能への影響が少 ないことや，正確な分腎機能の把握が困難であること などによりその機能評価は極めて困難であり, 腎保存 手術適応の簡便な指標が切望されている，従来より行 われている一定期間腎瘻を招いて腎機能が回復するか 否かを観察するといら方法 ${ }^{516)}$ では, 腎瘦留置期間の管 理は繁雑となり，しばしば感染を合併して腎㙉尿管粘 膜の線維化をきたし，その後の形成手術を困難なもの にする可能性がある77.レノグラム,レノシンチによる 分腎機能の定量的評価は非侵襲的方法として推奖され るが，尿路閉塞中はその機能が過少評価される可能性 があり，閉塞解除後の経過観察には有効であるが，回 復能の予測には適当ではないと考えられる ${ }^{8) 9}$. またク リアランス法を用いた分腎機能検査法では，正確な採
Fig. 5a Relationship between V/GFR of preoperative hydronephrotic kidney and the results of operation.

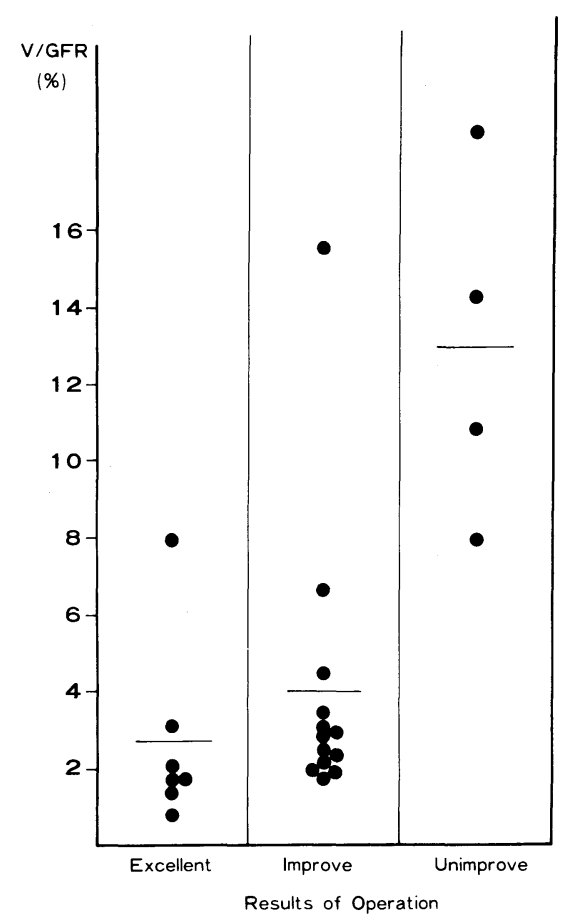

尿が困難であることから, spot 尿を用いた簡便な腎機 能評価法が望まれる，尿 $\mathrm{pH}$ の測定もある程度有用で あるが ${ }^{10}$. 採尿時の条件を一定とする必要があり, また 尿酸性化能障害は比較的早期における為, 高度に障害 された水腎症の残存機能の把握には不十分である1). 一方水腎症では尿中成分濃度が腎機能障害の程度に よって変化し，しだいに血中の值に近づくことを数室 の松下が明らかにして扣り ${ }^{11)}$ ，これを用いて各成分の 尿中排泄率を算出すると，高度に障害された水腎では 殊にV/GFR, FENa や著しく高値となり, 動物実験で はV/GFR $5 \%$, FENa $3 \%$ 罗回復の限界であった ${ }^{1)}$. 臨床例への応用に際しては, 腎监穿刺時の条件が一律 でないことや, 先天性水腎症では腎の発生, 発育上の 問題も考慮されなければならないが，今回の臨床例で の成績は, 動物実験で得られた結果にほぼ一致するも のであった。すなわち，手術時の年齢，先天性と後天 性の違いに関係なく, 水腎尿の尿中ナトリウム排泄率 が $3 \%$ 以下のものでは, いずれも閉塞解除後にIVP 上 の改善が得られた。しかしながら, 著明な改善例は, 15歳以下で FENa $2 \%$ 以のものに限られており, 殊 に 1 歳までに手術をおこなった 2 例では, その後の回 
Fig. 5b Relationship between FENa of preoperative hydronephrotic kidney and the results of operation.

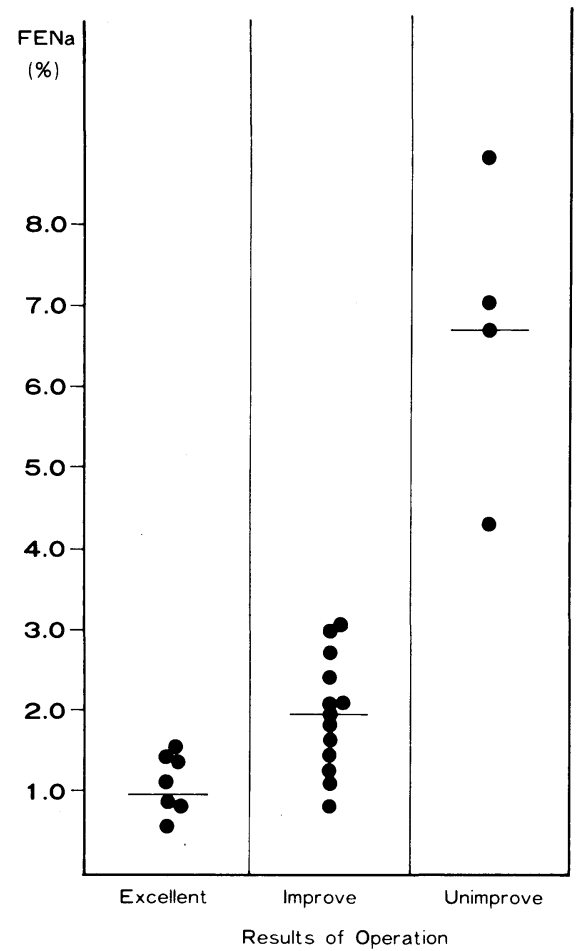

復は著しく, 腎の成長が閉塞解除後の腎機能の回復に 及ぼす影響の大きいことが示唆された。

IVPで腎機能を的確に評価し得るか否かについて は，否定的な意見が多いが12) 14)，今回の成績では，60 分以内に造影の得られたものは，全例腎孟尿の FENa が $3 \%$ 以下であり，60分以上の delayed film で造影の 得られた 3 例は，いずれも FENa が低值であった。 従って, 静脈性腎盂造影でなんらかの造影の得られる ものは，尿中ナトリウム排泄率も低值と考兄られ，腎 保存の方向で検討されるべきであろう，問題となるの はいわゆる不映腎であるが，近年このような不映腎に 対しても，超音波ガイド下に安全に腎盘穿刺を施行す ることが可能であり ${ }^{15)}$, 経皮的腎孟造影を含めて, 腎孟 尿成分の分析を行らことは容易である。そ結果が， 今回の成績にもとづけば，尿中ナトリウム排泄率が $3 \%$ 以下であれば，年龄や水腎の成因に関係なく，腎 保存手術の適応となろう，尿中ナトリウム排泄率が $3 \%$ 以上である場合には，腎孟穿刺時の条件を充分に 考慮したうえで，対側腎に代償性肥大が充分に抗こっ ており，患側による臨床症状や感染の危険が大きい場
Fig. 5c Relationship between FEK of preoperative hydronephrotic kidney and the results of operation.

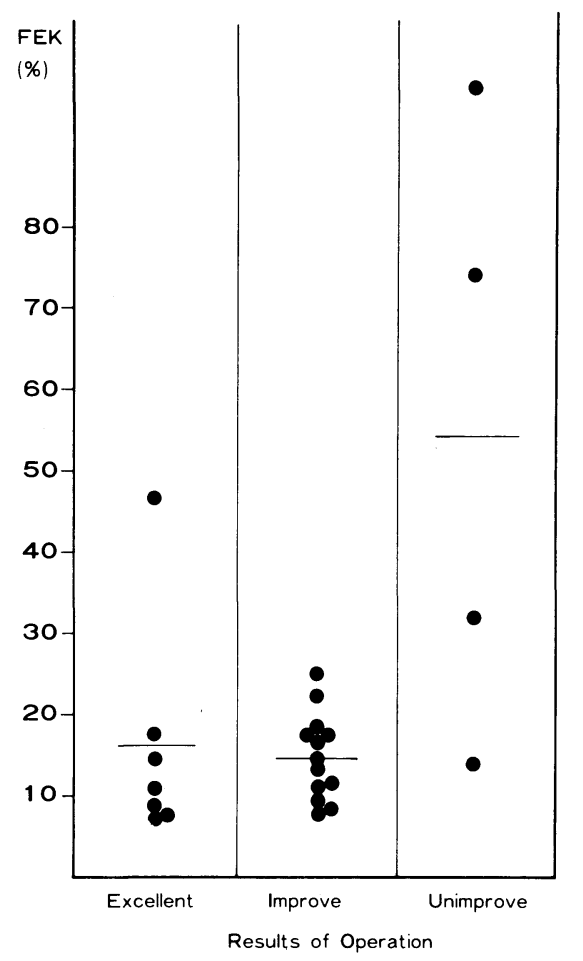

Fig. 6 Relationship between FENa of preoperative hydronephrotic kidney, age at operation and the result of operation.

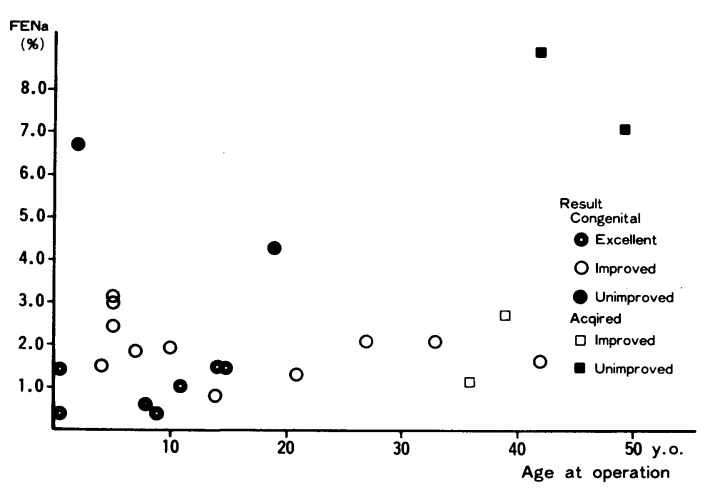

合には，腎摘もやむを得ないと考兄られた。

\section{結語}

1）偏側性水腎症の残存機能把握と回復能予測の目 的で, 35例の臨床例（先天性28例, 後天性 7 例）に対 して経皮的腎孟穿刺により腎孟尿を採取し，V/GFR， FENa，FEK を算出した。次に各例の静脈性腎㙉造影 
の所見を腎杯の形態, 造影に要する時間, 造影の濃度 から分類し，それぞれについて腎孟尿中各成分の尿中 排泄率との比較を扣こなった。その結果, 腎杯の形態 とこれらの值との間には相関は得られなかった。造影 時間と造影度は各成分尿中排泄率が低值のものほど良 好であったが，殊に造影が良好な例での FENaはいず れも $3 \%$ 以下であった。

2）血管造影をおこなった 9 例について, 患側腎動脈 の対腹部大動脈比を求め, 患側腎孟尿の各成分尿中排 泄率との比較及び術後結果との比較検討を扢こなっ た。その結果，患側腎動脈の対腹部大動脈比が $20 \%$ 以 上の例では, いずれも患側腎孟尿の FENa は $3 \%$ 以下 であり, 閉塞解除後に IVP 上の改善が得られた。

3）尿路閉塞解除後長期的に経過観察を括こなった 24 例について, 閉塞解除前の患側尿中各成分排泄率と 閉塞解除後の IVP 上の改善の有無を比較検討した。 そ の結果閉塞解除前の腎孟尿 FENa が $3 \%$ 以下のもの では, いずれも閉塞解除後に IVP 上の改善が得られた が，著明な改善は手術時の年齢が15歳以下で， FENa $2 \%$ 以下のものに限られた。

以上の結果より，偏側性水腎症の水腎尿中名成分排 泄率は, 水腎機能をよく反映し, 閉塞解除後の腎機能 回復能の指標として極めて有用と考兄られた。殊に水 腎尿中ナトリウム排泄率（FENa）が $3 \%$ 以下であれ ば, 閉塞解除により腎機能回復が期待されることが明 らかとなった。

$$
\text { 文献 }
$$

1）福崎 篤, 鈴木省司, 松下昌人, 折笠精一：水腎症 の研究. 第11報実験的水腎症に括ける尿中排泄率 の検討と回復能予測の試み. 日泌尿会誌, 74, 1169-1178, 1983.

2）藤野文雄：水腎症の知見補遺，第 1 編水腎症の統 計的観察. 名市大誌， 8，225-231，1958.

3）岡 直友: 水腎症の臨床的知見の補遺. 殊に拡張 せる上部尿路腔縮小の可能性並びに腎動脈像の腎 保存的手術適応決定上の価値. 日泌尿会誌, 56, 506-517, 1965 .

4) Johneton, J.H., Evans, J.P., Glassberg, K.I. and
Shapiro, S.R.: Pelvic hydronephrosis in children : A review of 219 personal cases. J. Urol., 117, 97-101, 1977.

5）大田黒和生：先天性水腎症と水尿管症（90症例の 観察). 臨泌, 24, 189-203, 1970.

6) Pode, D., Shapiro, A., Gordon, R. and Lebeneart, P.: Percutaneous nephrostomy for assessment of functional recovery of obstructed kidneys. Urology, 19, 482-485, 1982.

7) Parker, R.M. and Perlmutter, A.D.: Upper urinary tract obstruction in infants. J. Urol., 102, 355-360, 1969.

8) Djurhuus, J.C., Christianeen, D.L., Laseforged, J. and Nerstrom, B.: predictive value of renography and I.V. urography for the outcome of reconstructive surgery in patients with hydronephrosis. Acta Chir. Scand., 472, 37-41, 1976.

9) Chibber, P.J., Chisholm, G.D., Hergreave, T.B. and Marrick, M.V.: ${ }^{99 m}$ Tchnetium DMSA and the prediction of recovery in obstructive uropathy. Brit. J. Urol., 53, 492-495, 1981.

10) Ibrahim, A. and Fahal, A.H.: Reconvery of radiologicallyfunctionless obstructed kidneys. Brit. J. Urol., 54, 113-115, 1984.

11）松下昌人：水腎症の研究, 水腎尿中成分変化と腎 機能. 日泌尿会誌，73，904-916，1982.

12) Sherwood, T., Breckenridge, A., Dollery, C.T., Doyle, F.H. and Steiner, R.E.: Intravenou urography and renal function. Clin. Radiol., 19, 296-302, 1968.

13) Bartley, O., Bergtsson, U. and Stattin, S.: Urography in relation to renal function. Acta Radiol. Diag., 7, 289-398, 1968.

14) Mark Milkiemeyer, R. and Bioyce, W.H.: Validity of the intravenous pyelogram in assessment of renal function. Surg. Gyencol. Obstet., 135, 897-900, 1972.

15）千葉 裕, 棚橋善克, 原田一哉, 沼田 功：腎の超 音波診断（第 4 報），不映腎の診断における超音波 ガイド下経皮的腎㙉造影法の有用性について。 日 超医論文集，37，447-448，1980。

（1984年10月29日受付） 